\title{
Um sistema comercial-cultural de importação de porcelanas de mesa francesas no Brasil do século XIX
}

\section{A Commercial System for the Importation \\ of French Porcelain Tableware into Brazil in the Nineteenth Century}

Heloisa BARBUY ${ }^{1}$ https://orcid.org/0000-0001-6216-1924

${ }^{1}$ Museu da Faculdade de Direito

Universidade de São Paulo

Largo São Francisco, 95, São Paulo, SP, 01.005-010, Brasil

hbarbuy@usp.br

Resumo $O$ presente artigo propõe uma incursão pelos meandros do comércio de porcelanas de mesa francesas no Brasil do século XIX. Trabalhando na perspectiva da cultura material, busca compreender as características e valores que presidem a produção de porcelanas na França e apreender os mecanismos que se estabelecem, por meio do comércio de exportação-importação, no processo de introdução de um padrão francês nos usos e gostos da elite brasileira, que o adota como parte de seu modo de vida e de sua imagem de classe. Explora documentação relacionada ao comércio de porcelanas entre a França e o Brasil, em especial correspondência consular e arquivos manufatureiros franceses, e toma como eixo documental a coleção de porcelanas do Museu Paulista da USP como fonte material. Ao final, aborda o caso de uma casa comercial no Rio de Janeiro relacionada a um importante serviço de mesa.

Palavras-Chave cultura material, comércio, porcelana

Recebido: 07 ago. 2018 | Revisto: 03 set.2018 | Aceito: 03 out. 2018

http://dx.doi.org/10.1590/0104-87752019000100010

Varia Historia, Belo Horizonte, vol. 35, n. 67, p. 275-309, jan/abr 2019 
Abstract This article proposes to enter the meanderings of the French porcelain tableware trade in nineteenth century Brazil, taking the collection of the Museu Paulista of USP as a documentary axis. Working from the perspective of material culture, it seeks to understand the characteristics and values that governed the production of porcelain in France and to understand the mechanisms that were established through the export-import trade, in the process of introducing a French standard of uses and tastes to the Brazilian elite, who adopted it as part of their way of life and their class image. Documentation related to the porcelain trade between France and Brazil is looked at, in particular consular correspondence and French manufacturing archives. The tableware collection of the Museu Paulista of USP is taken as a documentary axis, as material sources. Finally, the case of a commercial establishment in Rio de Janeiro related to an important tableware service is looked at. KEYWORDS material culture, trade, porcelain

\section{INTRODUÇÃO}

Estudos recentes no campo da história da alimentação têm-se voltado para o aparato material que se desenvolve para dar suporte às refeições, dos talheres ao mobiliário (Algranti, 2016; Borrego, 2016). No âmbito das práticas sociais das elites, um grande investimento é feito nesse aparato, formando um cabedal de luxo, que ganha, assim, um sentido simbólico, desempenhando importante função nas chamadas artes da mesa.

Como nos mostra Carlos Eugênio Marcondes de Moura (2014), os inventários de fazendas muitas vezes registraram a existência de louças entre seus bens. Parece-nos, que, neste campo, as coleções desse tipo de objeto podem nos propiciar uma visão mais clara sobre o que foi esse aparato, no impacto e nos pormenores de sua materialidade, assim como pelo lugar que esse tipo de objeto ocupou nas conexões culturais tecidas nos meandros dos sistemas do comércio de importação. Não por outro motivo, Moura, como co-curador, reuniu alguns desses objetos 
numa exposição intitulada $O$ Café, da qual remanesce um rico catálogo (Araújo, 2000).

Assim, tomando como eixo documental as porcelanas de mesa francesas do acervo do Museu Paulista, pretendemos atingir uma melhor compreensão dos mecanismos pelos quais esse tipo de objeto de luxo se introduziu no aparato material de que a elite brasileira se cercou, no século XIX. Esta coleção compõe-se de 260 peças correspondentes a 65 serviços de mesa com marcas francesas, maioria no acervo. Tais objetos documentam um processo de introdução da estética francesa nos usos e gostos das elites brasileiras, enquanto elemento associado a uma noção de refinamento de classe social e fazendo parte do aparato material destinado a compor sua imagem.

A coleção foi essencialmente formada no início dos anos 1950, a partir da aquisição de três coleções privadas, ${ }^{1}$ quando era diretor do Museu Paulista, o professor Sérgio Buarque de Holanda. Também diversas doações ocorreram, esparsa e pontualmente. Em seu conjunto, muito se assemelha à coleção congênere do Museu Histórico Nacional (Rio de Janeiro) e àquelas de outras instituições brasileiras como o Museu Imperial (Petrópolis) e o Museu de Arte da Bahia (Salvador).

Entendemos que o sentido geral dessas coleções, quando de sua entrada nos museus, fôsse representar a História do Brasil em seu período imperial, durante o qual a formação de uma aristocracia brasileira era correntemente tomada como uma das provas da formação da Nação após a Independência política do Brasil, a isto se conferindo um sentido simbólico maior de construção do país (Moura, 2002).

Esta aristocracia então formada, preocupava-se em ter um modo de vida condizente com seu status e em construir sua própria imagem

1 Correspondência do Diretor do Museu Paulista, Sérgio Buarque de Holanda, ao Secretário de Estado dos Negócios da Educação (ao qual o Museu era então subordinado): Museu Paulista, Serviço de Documentação Textual e Iconografia: ofício n. 112 de 01/04/1950, n. 124 de 10/04/1950, n. 277 de 26/08/1950, n.318 de 05/10/1950, n. 323 de 09/10/1950 (ref. Coleçao Almeida Santos); ofícios n. 321 de 06/10/1950, n. 322 de 09/10/1950 (ref. Coleção Manuel Rabelo de Almeida); Coleção Evilásio Lopes (1951). Consta que os dois últimos fossem antiquários. Ver também, SANTOS, 1963. 
de classe. Foi neste sentido que importou da Europa e, sobretudo da França, todo um aparato material para cercá-la em suas residências urbanas e rurais. Assim, uma estética francesa se introduz nesses meios em que a origem dos objetos representa por si só uma garantia do bom gosto que se reputa adequado, gosto este que era frequentemente cultivado durante longas estadias de brasileiros na França. Importar da França numerosos objetos de luxo, caros e refinados, era então uma verdadeira moda, isto é, um gosto e uma necessidade social.

Muito poucos estudos foram desenvolvidos sobre essas coleções e o mais importante deles é a obra de Jenny Dreyfus, antiga curadora do Museu Histórico Nacional, que oferece o repertório mais completo existente sobre "a louça da aristocracia no Brasil". Mais de três décadas após o surgimento desse precioso trabalho, pretendemos apresentar uma contribuição ao estudo dessas porcelanas no Brasil, examinando outros aspectos de sua constituição original (Dreyfus, 1982).

Foi a observação das diferenças entre as abordagens feitas por museus brasileiros e franceses, quanto à porcelana, que nos impulsionou a empreender pesquisas que possam religar os dois universos que lhes deram origem no século XIX: de um lado, a produção manufatureira da França e, de outro, o consumo de objetos de luxo no Brasil. ${ }^{2}$ Ligando-os, o comércio entre os dois países.

A visão sobre a louça e outros tipos de objetos de interiores que predomina em nossos museus insere-os mais no universo do consumo do que naquele da produção como parece mesmo natural. A este propósito (embora falando de móveis e não de louças), Affonso Taunay, nos primeiros anos de exercício como diretor do Museu Paulista, ponderou:

Penso eu que a coleção de móveis antigos de São Paulo não deve ter em vista mostrar o adiantamento ou atraso das artes industriais entre nós, nos tempos coloniais; mas o gosto artístico, o conforto e os meios de fortuna dos nossos maiores. Naqueles tempos havia até falta

2 Este objetivo já estava presente no trabalho de Dreyfus, visto que fornece o histórico das diferentes manufaturas francesas e suas marcas presentes no acervo do Museu Histórico Nacional. 
de carpinteiros, quanto mais de artistas do mobiliário. Tudo, naquele tempo, assim até há bem poucos anos, deveria ter sido trazido de fora. Assim, parece que não nos deve preocupar a origem ou nacionalidade do móvel, para a coleção. ${ }^{3}$

Interessante observar que esta reflexão tenha sido feita e expressa por Taunay, o que explica também que houvesse pouca informação técnica sobre as peças do acervo, embora fossem altamente valorizadas no Museu quanto a seus usos sociais em tempos pretéritos e seu poder evocativo. Hoje, porém, propomos uma incursão também pelo universo da produção desses objetos em seus países de origem pois entendemos que o valor que lhes foi ali atribuído, relativo à suas qualidades técnicas e estéticas, participou fortemente dos critérios que orientaram sua escolha, pelas elites nacionais, tanto quanto pelas estrangeiras, para compor seus próprios ambientes. O gosto a que se refere Taunay vinculava-se a esse valor, a nosso ver.

\section{O UNIVERSO DA PRODUÇÃO MANUFATUREIRA FRANCESA E SUAS TENDÊNCIAS ESTÉTICAS}

No século XVIII, a porcelana torna-se uma alternativa à ourivesaria para a confecção de objetos refinados, consumidos apenas pelas classes altas. A própria ideia de refinamento, na França, associa-se claramente à perfeição do processo artesanal ou manufatureiro de objetos produzidos por meio de técnicas sempre elaboradas e reelaboradas, no que tange desde os materiais empregados até a concepção estética. O campo dessas produções no século XIX é o cruzamento entre arte e indústria, uma se alimentando da outra, indissociavelmente. Significa a aplicação, às criações modernas, de um saber-fazer imemorial, tecnicamente renovado. A este campo se deu o nome de artes decorativas; no que diz respeito às porcelanas, Sèvres é seu lugar por excelência (Brunet; Preaud, 1978). Manufatura pertencente ao Estado, Sèvres afirma-se, no

3 Carta de Taunay a Washington Luís apud MARTINS, 2012, p.99-100. 
século XIX, especialmente sob a direção de Alexandre Brongniart, de 1800 a 1847, como laboratório de pesquisas químicas e mineralógicas e centro de estudos sobre história das artes cerâmicas (é em função desta história que se cria, em 1824, o Museu de Cerâmica), tudo aplicado ao desenvolvimento de técnicas de fabricação de obras em porcelana, em todas as suas etapas, desde a composição das massas até a decoração final dos objetos. ${ }^{4}$ Sèvres é a referência matricial de todas as porcelanas francesas do século XIX. A ideia de artes decorativas estaria ali apenas contida naquela de artes industriais, de sentido mais amplo e que corresponde melhor, talvez, às características deste grande centro de criação e produção de objetos artísticos de alto refinamento, ainda hoje em pleno funcionamento.

A propósito, a expressão artes industriais foi utilizada para nomear um serviço produzido na Manufatura de Sèvres, entre 1820 e 1835, que nos parece muito emblemático do século XIX francês, o Service des arts industriels. ${ }^{5}$ Era constituído por 162 peças ${ }^{6}$ destinadas a "ilustrar, de maneira pitoresca, o progresso tecnológico aplicado a diferentes ofícios", tal como o define Pierre Ennès (Ennès, 1990, p.89). De acordo com Ennès, este serviço foi concebido pelo próprio Alexandre Brongniart, que para sua realização escolheu o pintor Jean-Charles Develly, especialista em pinturas a partir da observação do real. Foi assim que, sob a direção de Brongniart, Develly percorreu vários ateliês e oficinas de Paris e região para esboçar as cenas que pintaria sobre as peças do serviço em questão. Entre os diversos ofícios representados, como o de joalheiro,

4 BRONGNIART, Alexandre. Traité des arts céramiques ou des potteries considerées dans leur histoire, leur pratique et leur théorie. Troisième édition avec notes et additions par Alphonse Savétat. Paris: Dessain et Tolra, 1977 (fac-sim. ed. 1877); (1.ed. 1844).

5 Ao longo de todo o artigo, optamos por traduzir as citações em francês e inglês, com traduções nossas, mas não os títulos de serviços ou obras e tampouco os nomes de ruas.

6 Segundo Pierre Ennès, um serviço de sobremesa de Sèvres, normalmente era composto por 98 peças mas no caso do Service des arts industriels, Brongniart foi acrescentando, pouco a pouco, novos ofícios que deveriam ser nele representados por pinturas, o que fez aumentar o número de peças (ENNÈS, 1990). De acordo com Long, durante muito tempo, eram conhecidas apenas 19 delas, mas depois se descobriu que em 1836, o Service des arts industriels contava com 162 peças (LONG, 1996). 
tamanqueiro ou litógrafo, há também representações sobre a fabricação da própria porcelana, feitas a partir da observação de ateliês da Manufatura de Sèvres: Les moufles, Tourneurs, Atelier de peinture, Moulin et marche des pâtes, Brunissage et fonds, Couverte et encastage, Sculptures et garnisseurs (Long, 1996).

Este tipo de representação faz parte de um culto à indústria ou, mais do que isso, de uma cultura própria à sociedade industrial do século XIX ocidental; é sua linguagem e sua prática: tornar visível e, assim, compreensível, o poder da indústria sobre o mundo natural, por meio de representações iconográficas ou tridimensionais.

Ao longo do século XIX, a porcelana participou dos movimentos das artes decorativas mas com as características que lhe são próprias, como integrante das chamadas artes do fogo (vidraria, esmaltes, cerâmicas). Entre as cerâmicas, aproxima-se da faiança mas se diferencia dela especialmente pelo acabamento que a composição de suas massas lhe permite. Para atingir bons resultados em porcelana, são necessários conhecimentos científicos e práticas muito mais complexos do que os exigidos pela faiança. Além disso, à parte Sèvres, que lhe resiste por princípio, a mecanização das manufaturas avança rapidamente no século XIX (Fay-Hallé; Mundt, 1983). Isto quer dizer que entre o artesanal e o industrial, as produções de porcelana estariam mais inseridas no mundo industrial, o que lhes dá um lugar de honra na sociedade moderna, vinculada à indústria como valor, como sinônimo de sua própria capacidade. "Está viva a disputa entre os partidários da faiança e os partidários da porcelana e já dura há muito tempo no reino da cerâmica", dizia o texto de um catálogo comercial. E assinalava: "Em geral, os artistas conferem o primeiro lugar à faiança, enquanto a alta sociedade prefere a porcelana. / Aos primeiros, a faiança parece mais decorativa, enquanto os últimos consideram a porcelana mais elegante e, para usar uma expressão de sua língua, mais comme il faut ".

7 ENAULT, Louis. “La Porcelaine”. In: GRAND DEPOT E. BOURGEOIS, catálogo, [1880]. Acervo da Bibliothèque Forney, Paris. Louis Enault foi romancista, jornalista e crítico de arte francês, nascido em Isigny, Calvados, em 1824, e falecido em Paris, em 1900. 
As exposições universais são ocasiões para um julgamento oficial de produtos. Os relatórios dos júris e outros relatórios oficiais sobre as seções cerâmicas ou, às vezes, sobre a porcelana em particular, são documentos privilegiados para a compreensão dos valores e questões que se colocavam, no século XIX, nos meios especializados. O relatório escrito pelo pintor Lameire, sobre "as porcelanas modernas" na Exposição de 1878 , destaca-se dos demais justamente porque seu autor é um artista. ${ }^{8}$ Sua preocupação é estética, antes de mais nada, mas ele bem sabe que o resultado estético depende de sua integração com os elementos técnicos. A porcelana será julgada de acordo com sua finalidade artística mas trata-se de uma arte industrial, em que a função do objeto, sua utilidade, é elemento essencial de sua própria constituição: "harmonia completa entre a destinação do objeto, o material que o compõe e os recursos ornamentais de que se dispõe". 9

No que se refere à decoração, quanto mais resultar de uma concepção fundada sobre conhecimentos de história da cerâmica, mais será valorizada. O equilíbrio dos "elementos mais simples, repetidos, alternados ou arranjados com sabedoria" ${ }^{10}$ será considerado de bom gosto enquanto as execuções muito carregadas, com excesso de elementos ou pouca superfície branca aparente, serão consideradas pesadas. A este respeito, é preciso assinalar que são os brancos, as superfícies sem decorações coloridas, que permitem julgar a qualidade da porcelana em si, por sua translucidez, resistência e acabamento. É por esta razão que a manufatura Jean Pouyat, de Limoges, torna famosos os seus brancos - conjuntos inteiramente brancos — na Exposição de 1878 (Meslin-Perrier, 1994;

8 LAMEIRE, Charles. Rapport adressé à M. le Ministre de l'Instruction publique et des Beaux-Arts par M. Lameire au nom de la Commission de perfectionnement de la Manufacture nationale de Sèvres sur les porcelaines modernes qui ont figuré à l'exposition universelle de 1878. Nancy: Berger-Levrault et Cie, 1879. Lameire atuava como pintor na Manufatura de Sèvres e elaborou o citado relatório na condição de membro da Comissão de Aperfeiçoamento de Sèvres.

9 LAMEIRE, Charles. Rapport adressé à M. le Ministre de l'Instruction publique ..., p.4.

10 LAMEIRE, Charles. Rapport adressé à M. le Ministre de l'Instruction publique ..., p.21. 
Albis; Horts, 1992). ${ }^{11}$ Mas os produtos apresentados por Ad. Hache \& Pépin le Halleur, de Vierzon, são os preferidos de Lameire, descritos como "belos serviços de mesa de fundo branco, suas xícaras com uma decoração bem concebida, discreta e de uma feliz harmonia". ${ }^{12}$ Harmonia, porém, não devia significar monotonia: a variedade de formas e as tonalidades bem sucedidas (duas qualidades que o relatório de Lameire aponta, por exemplo, nas peças de Pillivuyt), ${ }^{13}$ sejam suaves ou fortes, também serão valorizadas, as primeiras enquanto sinal de imaginação criativa e as demais como prova de perfeição técnico-científica.

Outra questão decorativa que integra os critérios de julgamento é a "divisão do espaço", isto é, a distribuição dos elementos decorativos. Lameire diz, por exemplo, que "a divisão do espaço deixa a desejar em algumas peças" de Demartial \& Taillandier e aponta "uma divisão falsa de espaço" em ateliers dedicados somente à decoração. ${ }^{14}$ Dois artigos de Laurens d'Albis guiam-nos pelo que ele considera uma verdadeira revolução da decoração em porcelana: um modelo neoclássico de decoração domina toda a primeira metade do século XIX ou mais; determina um motivo central no fundo de um prato ou outra peça, por exemplo (em muitos casos até mesmo este motivo depois desaparece), cercado por frisos circulares (Albis, 1998; 1993). O autor define este modelo como "simétrico-centrado-cercado" (figura 1) e o interpreta como uma golilha de ferro aprisionadora, que será depois rompida por um movimento de liberação que suprime os frisos circundantes, a simetria e a centralidade para dispor os elementos decorativos de maneira aparentemente aleatória. Este partido decorativo vai se desenvolvendo até que a borda, a aba e o fundo de um prato não representem mais limites: os elementos

11 No Museu Paulista, há peças correspondentes a sete serviços produzidos por Pouyat.

12 LAMEIRE, Charles. Rapport adressé à M. le Ministre de l'Instruction publique ..., p.23. No Museu Paulista, há peças correspondentes a quatro serviços produzidos por Hache.

13 LAMEIRE, Charles. Rapport adressé à M. le Ministre de l'Instruction publique ..., p.23. No Museu Paulista, há peças correspondentes a 15 serviços produzidos por Pillivuyt.

14 LAMEIRE, Charles. Rapport adressé à M. le Ministre de l'Instruction publique ..., p.2 [4]. 
decorativos não precisam mais terminar, visualmente falando, nos contornos das peças. Chega-se depois à estabilidade com uma distribuição ternária dos elementos decorativos. O início desta revolução é marcado pelo Serviço Rousseau, de inspiração japonesa, concebido por Félix Bracquemond (Bouillon; Meslin-Perrier, 2005). ${ }^{15}$

Figura 1: Prato do Serviço do Barão do Rio Branco (cf. Dreyfus, 1982, p.313), 1888-1889, provavelmente. Traz a marca da casa comercializadora Grand Dépôt E. Bourgeois, Paris.

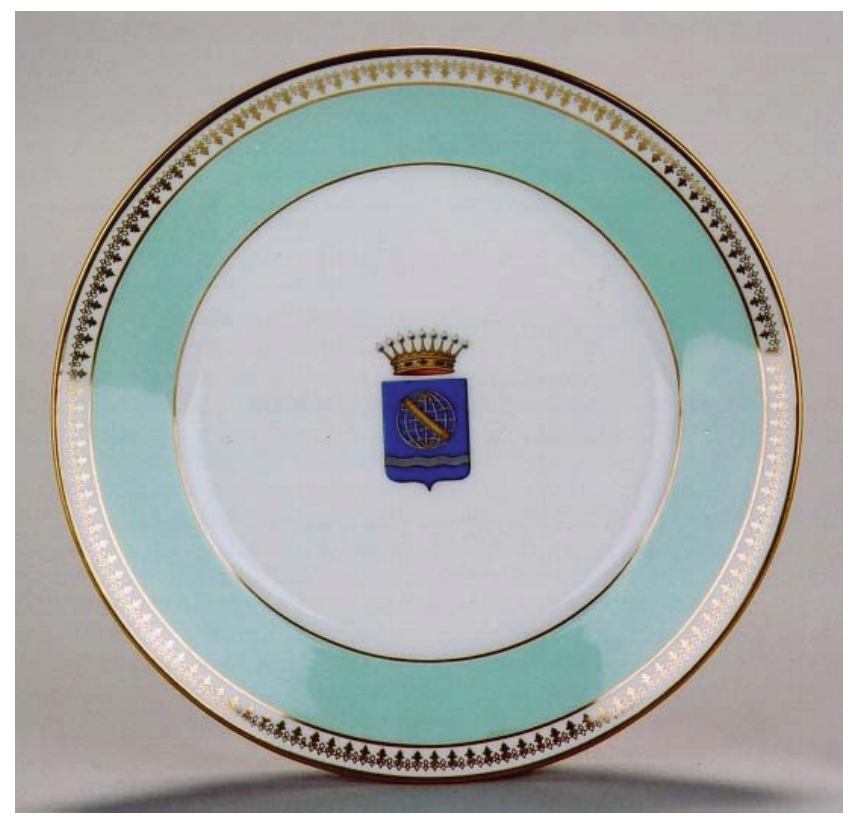

Fonte: Acervo do Museu Paulista da Universidade de São Paulo Créditos fotográficos: Hélio Nobre e José Rosael

15 Referem-se a Eugène Rousseau, comerciante-editor de porcelanas em Paris, que encomendou o serviço a Bracquemond. Sobre o conceito de comerciante-editor, ver adiante. 
Recentemente, Bracquemond foi redescoberto como artista atuante no movimento impressionista e, tanto quanto Émile Gallé, precursor do art-nouveau. Em Bracquemond, a inovação se dá sobretudo pela aplicação, pela adaptação à cerâmica, do conhecimento das artes gráficas que são a sua especialidade; é também das artes gráficas que ele traz a estética e os motivos japoneses (Bouillon; Meslin-Perrier, 2005). O período de 1872 a 1880, em que este artista dirige, para Haviland \& Co, o “atelier d'Auteuil", nos arredores de Paris, é considerado muito criativo e produtivo. Sob a direção geral de Charles Haviland, Bracquemond cria decorações ao mesmo tempo inovadoras e comercialmente bem-sucedidas. O Museu Paulista tem em seu acervo um prato de um serviço de sobremesa decorado com decalques ${ }^{16}$ em motivos japoneses, ${ }^{17}$ entre os quais uma "graça japonesa", figura feminina com quimono, encontrada em uma prancha de Bracquemond (Bouillon; Meslin-Perrier, 2005). ${ }^{18}$ Esta peça mostra bem a distribuição mais solta dos elementos decorativos. Tem ainda um friso cercando a borda, mas este é estreito e tem a leveza de um cor-de-rosa suave (figura 2). Além disso, nesse havia uma variação na decoração de um prato e outro como se pode ver numa das páginas de um catálogo da manufatura Haviland datado de 1879, o que confere ainda mais modernidade a esse serviço. ${ }^{19}$

$16 \mathrm{O}$ uso do decalque em lugar da pintura à mão faz parte do processo de mecanização/industrialização da porcelana.

17 Pertenceu ao Barão de Avellar e Almeida.

18 Os curadores não incluíram este serviço na exposição por considerá-lo como criação mais devida às solicitações de Charles Haviland do que a um desejo artístico do próprio Bracquemond (informação verbal fornecida por Chantal MESLIN-PERRIER, em 2005).

19 HAVILAND \& Co. Tarif des porcelaines et des faïences Haviland \& Co (Catálogo comercial, 1879, cópia fotográfica). Acervo do Musée des arts décoratifs - Biblioteca, Paris, p.26. 


\section{Heloisa BARBUY}

Figura 2: Prato do serviço de sobremesa do Barão de Avellar e Almeida, anos 1880. Traz as marcas da manufatura Haviland \& Co., Limoges, e da casa comercializadora Vizcaya Irmãos, Rio de Janeiro.

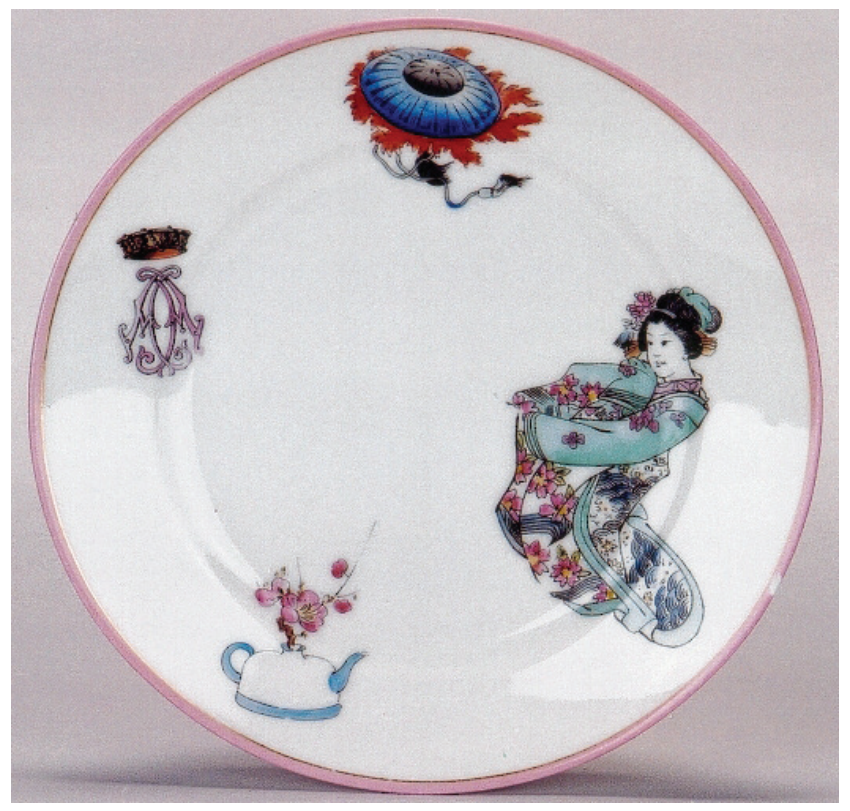

Fonte: Acervo do Museu Paulista da Universidade de São Paulo Créditos fotográficos: Hélio Nobre e José Rosael

Em Gallé (e, com ele, na Escola de Nancy) ${ }^{20}$ serão os conhecimentos botânicos, associados a um profundo domínio técnico da manufatura de porcelanas que impulsionarão a inovação. Entretanto, não se trata de copiar a natureza, mas sim de interpretá-la, fazendo-se a fusão das formas e cores com o material cerâmico ou o vidro. ${ }^{21}$ Daí resultará um simbolismo em cerâmica.

20 L'ECOLE DE NANCY, 1999.

21 Estas idéias também foram formuladas por Lameire no relatório sobre a porcelana citado acima, 1879. 
Em suma, a tendência maior à liberação que invade, plena de vitalidade, todas as artes nas últimas décadas do século XIX, será sentida também nas artes cerâmicas. O Oriente e a Natureza, muitas vezes associados, serão seus referenciais.

\section{O COMÉrCio FranÇA-Brasil}

\section{E A DIFUSÃO DE MARCAS FRANCESAS}

Encontram-se, na França, muito poucos dados sobre casos concretos de compras de porcelanas francesas realizadas por brasileiros ou por estrangeiros instalados no Brasil, antes de mais nada porque quase todos os arquivos comerciais de manufaturas francesas de porcelanas desapareceram. Os arquivos de Sèvres são uma exceção e nos permitem apreender o que podem ter sido os sistemas comerciais estabelecidos neste ramo. Entretanto, por suas próprias características de manufatura estatal, sem objetivo principal de fornecimento a particulares, não se poderia encontrar uma grande abundância de dados neste sentido.

No exame de duas séries documentais pesquisadas - série de livros de registro de encomendas feitas por particulares à Manufatura de Sèvres e série de correspondências a estas relativas,$-{ }^{22}$ pudemos encontrar três encomendas feitas por brasileiros: ${ }^{23}$ a primeira delas por um joalheiro e empresário, em 1891, "M. Luís de Rezende à Rio de Janeiro", 4 de um serviço de 113 peças com "filete de ouro e monograma" (não se

22 Na série de livros de registro faltam os anos de 1900 a 1913 e na série de correspondências relativas a estas encomendas faltam os anos de 1900 a 1902.

23 Há outros nomes luso-brasileiros como Carvalho, Azevedo, Souza Leão, dos quais não pudemos saber a origem precisa.

24 Sobre Rezende como colecionador de arte que vivia entre o Rio de Janeiro e Paris, ver KNAUSS, 2001. Para registro oficial sobre ele como empresário exportador de diamantes brutos, ver Decreto n. 2.589/1897, que autorizava o funcionamento, no Brasil, da companhia franco-brasileira de mineração Boa Vista. A joalheria de Luís de Rezende na rua do Ouvidor, no Rio de Janeiro, é citada no romance Flor de Sangue, de 1897, de romancista Valentim Magalhães. Ver também nota 69. 
menciona qual seria o monograma)", a expedir em 30 de maio, tudo embalado, para o Sr. [Des Vernine], 48 rue d'Hauteville"; ${ }^{25}$ outras duas por agentes diplomáticos brasileiros: "Sr. Alberto de Faria / Legação do Brasil Paris", em 1900; ${ }^{26}$ para o Consulado do Brasil, de uma xícara de café do "Serviço D borda lisa com decoração de esmalte e douração segundo um modelo fornecido", em 1914. ${ }^{27}$

É possível perceber, nestas séries documentais, alguns outros elementos, que são de interesse sobre o comércio de porcelanas em geral: $\left.1^{\circ}\right)$ mesmo sendo uma manufatura nacional, tendo por objetivo fornecer ao Estado e a órgãos oficiais, Sèvres pratica também a venda de peças a comerciantes de Paris, ${ }^{28}$ assim como a manufaturas privadas francesas, ${ }^{29}$ apesar de que nunca em grandes quantidades, no máximo um ou dois serviços, quando não peças unitárias. Nos dois tipos de casos, normalmente as peças são também decoradas em Sèvres; $2^{\circ}$ ) há várias encomendas a partir do interior da França e de outros países ao que corresponde todo um sistema de expedições, transportes e pagamentos, mas poucas encomendas são de fora da Europa. Estes dois elementos juntos - um número considerável de encomendas feitas por comerciantes franceses e a quase inexistência de encomendas feitas a partir de regiões não europeias - reforça o papel que se deve atribuir ao comércio de exportação/importação realizado por casas francesas em conexão com comerciantes instalados em outros países, como o

25 Archives de la Manufacture Nationale de Sèvres. Livre. Registre de Commandes de 1887 à 1892 (mai. 1891 e 29 jun. 1891); Livre Registres de Commandes 1891 à 1896, p.2.

26 Conteúdo da encomenda incompreensível, Archives de la Manufacture Nationale de Sèvres, Livre « Registres de commande 1896-1900», 1900, p.226.

27 Archives de la Manufacture Nationale de Sèvres, Livre. Registre de Commandes de 1913 à 1920 (20 jun. 1914), p.57, commande n. 3395.

28 Freqüentemente, há encomendas feitas por E. Bourgeois, do Grand Dépôt, uma das maiores lojas de porcelanas de Paris; por Lerosey, comércio e ateliê de decoração; assim como algumas encomendas feitas por Dommartin; Klotz e outros cujas marcas estão presentes em peças do acervo do Museu Paulista.

29 Encontram-se nos Archives de Sévres registros de encomendas feitas por Haviland e por Redon, de Limoges, por Hache e por Pillivuyt, do Berry, entre outros, todos com marcas presentes no acervo do Museu Paulista. 
Brasil. Quer dizer que a entrada de serviços de mesa franceses no Brasil deve ter-se realizado normalmente por intermédio de casas comerciais exportadoras/importadoras e muito menos frequentemente por encomendas feitas diretamente por particulares a manufaturas francesas.

No momento de fazer as encomendas aos importadores, além de ser possível escolher, a partir de catálogos, a forma e a decoração desejadas, também havia a opção de solicitar a inclusão de monograma (com ou sem coroa), brasão ou outras opções, a cada uma delas correspondendo preços específicos. ${ }^{30}$ Foi por meio desse sistema que os titulares do Império brasileiro puderam personalizar suas louças. Veja-se, por exemplo, o prato que pertenceu ao Barão de Avellar e Almeida, acima citado, no qual se pode notar, entre os elementos decorativos, o seu monograma "AA" com a coroa de barão (figura 2).

Quanto à difusão de marcas de fabricantes franceses no Brasil, tomemos como objeto de análise a coleção do Museu Paulista. O fabricante do qual há mais serviços de mesa representados nesse acervo (15 serviços) é Pillivuyt \& Cie, da região do Berry. Neste caso, a questão que se coloca é entender o porquê de uma tal presença no Brasil se as porcelanas dessa região não eram aparentemente tão célebres quanto as de Paris ou Limoges. Uma das hipóteses vincula-se à história de uma mulher da família Pillivuyt, que se instala "no Brasil, onde difunde peças notáveis e monta as mesas mais importantes" (Bon, 1998, p.7). Outra explicação seria simplesmente a vizinhança que poderia haver entre a casa comercial de Pillivuyt e alguns comerciantes que exportavam porcelanas para o Brasil, instalados na rue de Paradis, ${ }^{31}$ o grande centro parisiense de comércio de porcelanas no século XIX. ${ }^{32}$

30 GRAND DEPOT E. BORGEOIS, catálogos comerciais de 1880 [por nós datado como de c.1903], [1889] [1890-A], [1890-B], [1896], [1900], 1904, [1905], 1910, 1912, 1913. Acervos da Bibliothèque Forney e Biblioteca do Musée des Arts Décoratifs, ambas em Paris.

31 AU BON MARCHÉ. Guide illustré du Bon Marché: l'Exposition et Paris au vingtième siècle. Paris: Magasin du Bon Marché, 1900, p.282.

32 Alguns casos são das casa comerciais cujas marcas encontram-se em peças do acervo do Museu Paulista: Klotz, na rue de Paradis; Gauvain, na rue d'Hauteville; Dommartin, na rue des Petites Ecuries, todas no $10^{\circ}$ distrito administrativo de Paris (10 arrondissement), que, juntamente com o $9^{\circ}$ distrito, formava uma região em havia uma concentração de depósitos e casas de exportação. 
Sobre esta questão, também seria preciso saber se as porcelanas Pillivuyt, produzidas em Mehun-sur-Yèvre, eram difundidas no Brasil como sendo provenientes de Limoges ou de Paris, uma vez que a região do Berry se situa entre ambas; uma identificação com Paris seria muito compreensível uma vez que antes de 1900 as marcas Pillivuyt não faziam menção a Mehun e sim a Paris, onde esta manufatura tinha sua casa comercial. O grande sucesso atingido por Pillivuyt nas exposições universais a partir de $1867^{33}$ também poderia explicar o interesse de brasileiros por suas porcelanas mas o fato é que cinco dos quinze serviços em questão são anteriores a esse ano, de acordo com as marcas de fábrica que apresentam. ${ }^{34}$

Depois de Pillivuyt, Haviland, de Limoges, é a marca mais presente no acervo de porcelanas do Museu Paulista, com peças correspondentes a 13 serviços. A difusão dessa marca no Brasil não é de se estranhar, uma vez que, segundo Chantal Meslin, essa manufatura tinha "uma vasta rede de distribuição", "um lugar preponderante no mercado de Limoges" e "as exportações tinham um lugar considerável nas vendas da empresa” (Meslin-Perrier; Segonds-Perrier, 2005, p.205). Felizmente, parte dos arquivos desta manufatura foi preservada e doada aos Archives départementales de la Haute-Vienne em 1992. ${ }^{35}$ Pelo exame de algumas das séries que a integram, aparentemente o único país com o qual a Haviland mantinha um comércio de porcelanas constante e realmente importante do ponto de vista comercial era os Estados Unidos mas há menções a outros mercados.

Foi em grande medida com base nesta documentação que Nathalie Valière escreveu uma obra sobre Charles Edward Haviland, um dos filhos do americano David Haviland que, em 1842, fundou a Manufatura Haviland em Limoges (Valière, 1992). Nesta obra a autora afirma que o comércio de exportação para os Estados Unidos era realmente o

33 Pillivuyt \& Cie obteve medalhas nas exposições de Paris em 1867, 1878, 1889 e, em 1900, a medalha de ouro com o grande prêmio.

34 Serviços do Barão de Catumbi, Barão de Drumond, Barão de Ipanema, Barão de Itambé, Barão do Rio Preto.

35 Archives Departementales De La Haute-Vienne, Haviland, 1993. 
principal da Haviland, que tinha um volume relativamente pequeno de negócios na França. No que diz respeito a outros mercados, Haviland exportava para cidades em todas as partes do mundo, mas em graus variáveis. Quanto à América Latina, Valière nos indica que o comércio era considerável; que "se originava do comércio da empresa no sul dos Estados Unidos e, mais particularmente, de Nova Orleans, graças a seu agente, Nartigue \& Bigourdan, que mantinha correspondentes no México, em Havana e em Buenos Aires"; que a casa se implanta em Havana (que, aos olhos de Ch. Ed. Haviland, era "um dos melhores mercados para a boa porcelana, principalmente aquela com decorações ricas"), no México e no Rio de Janeiro (Valière, 1992, p.184). Prova da existência de um comércio organizado no Rio de Janeiro é que havia naquela cidade um correspondente de Haviland cuja marca pode ser encontrada em alguns dos serviços de mesa pertencentes à coleção do Museu Paulista: a marca de "Vizcaya Irmãos / Rio de Janeiro Paris", na qual se inscreve a marca "H\&Co", ${ }^{36}$ do fabricante. As peças já eram produzidas originalmente com marca da fábrica e aquela da casa importadora. Há registros da Casa Vizcaya nos almanaques comerciais do Rio de Janeiro ${ }^{37}$ para os anos de 1885 et $1886 .{ }^{38}$

Sobre este comércio na América do Sul, encontramos, nos arquivos da Haviland, apenas alguns impressos e cartas de companhias de transporte marítimo que eram enviados à manufatura Haviland como publicidade ou ofertas de serviços e preços: The Pacific Steam Navigation Company/Compagnie de navigation à vapeur Pacifique: serviço postal acelerado na Pallice (La Rochelle) e Valparaíso (Chile) (s.d.); Compañia Transatlántica, serviço regular para o Brasil, La Plata e Pacífico (s.d.);

36 No acervo do Museu Paulista, há peças com esta marca, correspondentes a quatro serviços.

37 ALMANAK administrativo, mercantil, e industrial do Rio de Janeiro ("Almanaque Laemmert"). Rio de Janeiro: irmãos Eduardo e Henrique Laemmert, 1844 a 1889.0 ALMANAK será aqui referido apenas como Almanaque Laemmert, como é mais conhecido. Fundado no Rio de Janeiro pelos irmãos Eduardo e Henrique Laemmert, foi publicado anualmente de 1844 a 1889 sob a direção destes editores. A partir de então, aos cuidados de outras editoras mas conservando o nome.

38 Almanaques Laemmert para 1885 e 1886. 
N. Estrabaut, transporte de porcelanas em caixas ou barricas para o Rio de Janeiro, entre outras cidades fora do Brasil (1900); Agence générale maritime: carta oferecendo serviços, na qual se sugere à manufatura Haviland que evite o porto de Bordeaux, no qual se praticariam taxas muito elevadas, trocando-o pelo porto do Havre, no qual esta companhia se dizia capacitada a oferecer "um serviço rápido, regular e cuidadoso para o Brasil, assim como para La Plata". ${ }^{39}$ São indícios do interesse que Haviland podia ter pelo comércio com a América do Sul e da importância que este comércio teria, já que se mostra suficientemente significativo para suscitar publicidade e ofertas de companhias de navegação e transporte atuantes na região.

Um outro caso a mencionar é o do Grand Dépôt E. Bourgeois, uma das duas maiores lojas de porcelanas de Paris, tipo de iniciativa comercial, empreendida por um certo tipo de comerciante chamado "editor", que, segundo Régine de Plinval de Guillebon, “era, em princípio, um comerciante que vendia, em sua loja, modelos exclusivos encomendados por ele a artistas ou a manufaturas, mas que não possuía ateliê próprio em seu nome ..."; ainda segundo essa autora, "os dois editores mais conhecidos foram [Eugène] Rousseau e [Émile] Bourgeois” (Guillebon, 1995, p.209). Tendo fundado a loja em 1863 (em um edifício que existe ainda hoje), no $9^{\circ}$ distrito, já mencionado na nota 32 , vemos por dados de sua biografia ${ }^{40}$ e pelos catálogos de sua loja, ${ }^{41}$ que Émile Bourgeois pode ser considerado um comerciante de vanguarda pelas características modernas de seu estabelecimento: concentração de um só gênero de produto (cerâmicas/artes da mesa) e em grande quantidade e variedade tanto no que se refere aos modelos oferecidos como à sua procedência, já que era representante das principais manufaturas inglesas neste ramo.

39 Archives Departementales De La Haute-Vienne, Haviland, 1993, Correspondance reçue des expéditeurs (par mer), 1899-1904.

40 MCCOLL, P. Le Grand Dépôt, dat./ms., 5p., s.l., s.d. Manuscrito sem data do qual pudemos tomar conhecimento e obter uma cópia graças à generosidade de Régine de Plinval de Guillebon.

41 Catálogos consultados na Bibliothèque Forney e no Musée des Arts Décoratifs (Biblioteca), Paris. 
Bourgeois vincula-se a um modelo de comerciante moderno e por isto mesmo deseja atingir um status mais alto. Reivindica para si um papel importante na difusão das cerâmicas, no mesmo nível - dentro do mesmo sistema - que as exposições de arte, as exposições universais e os museus, o que se pode perceber nos textos de cunho literário ou erudito que imprime em seus catálogos. ${ }^{42}$

Há, no Museu Paulista, peças com a marca do Grand Dépôt E. Bourgeois, que correspondem a dois serviços de mesa, um do Barão de Ataliba Nogueira e outro do Barão do Rio Branco (figura 1).

\section{AS GRANDES LINHAS DO COMÉRCIO DE PORCELANAS ENTRE A FrANÇA E O BRASIL}

Nas estratégias de produção e comércio de porcelanas, uma oposição entre objetivo artístico (traduzido por qualidade, refinamento e originalidade a altos custos) e objetivo comercial (traduzido por quantidade, gosto popular e imitação a baixos custos) encontrou seu auge na concorrência entre a porcelana francesa e as porcelanas e faianças inglesas e alemãs no mercado estrangeiro. Esta oposição pode ser acompanhada em detalhes, ao longo do século XIX, para o caso brasileiro, na correspondência consular hoje preservada nos Archives Nationales de France e nos Archives du Ministère des affaires étrangeres, ambos em Paris. Se casos particularizados são mais difíceis de encontrar, as linhas gerais de realização do comércio de porcelanas entre a França e o Brasil tornam-se bastante claras graças a esta correspondência, complementada, ainda, pela documentação das câmaras de comércio. ${ }^{43}$

42 GRAND DEPOT E. BOURGEOIS, catálogos. Acervo da Bibliothèque Forney, Paris.

43 Archives de la Chambre de Commerce de Paris; Archives de la Chambre de Commerce et d'Industrie Marseille-Provence. Marseille, cidade portuária de onde partiam navios para o Brasil. Quanto a Bordeaux, outra cidade portuária de onde também partiam navios para o Brasil, praticamente todos os arquivos do século XIX se perderam num incêndio. FAVIER, 1984. 
A parte desta correspondência que diz respeito a comércio e indústria, ${ }^{44}$ é de grande interesse para a presente análise em função dos boletins comerciais elaborados pelos cônsules franceses no Brasil, dos documentos relativos à Câmara de Comércio Francesa do Rio de Janeiro e, sobretudo, dos relatórios específicos sobre alguns ramos de comércio que fazem rico exame dos contextos brasileiros a que se referem e a aspectos de sua relação com a França e outros países.

Em 1883, uma enquete lançada pelo Ministère des affaires étrangères junto a vários consulados em todas as partes do mundo, incluiu o Consulado da França no Rio de Janeiro. ${ }^{45}$ Consistia em sete questões visando compreender as reais possibilidades para a exportação da porcelana francesa: $1^{\circ}$ ) quais eram as taxas aduaneiras, $2^{\circ}$ ) se havia consumo local deste produto, $3^{\circ}$ ) se havia uma exportação deste produto, $4^{\circ}$ ) que tipos de porcelana eram consumidos localmente, $5^{\circ}$ ) qual era a importância do mercado local, $6^{\circ}$ ) quais eram as casas com as quais seria possível estabelecer relações comerciais, $7^{\circ}$ ) qual era a diferença de valor entre o franco e a moeda local. Com exceção dos Estados Unidos (principalmente Nova York $)^{46}$ e do Egito, onde, segundo as avaliações consulares, o consumo de porcelanas era considerável (e de alguns outros países nos quais não havia consumo deste produto), os demais cônsules dão respostas semelhantes sobre o consumo local de porcelana, como no caso do Rio de Janeiro: o consumo "é restrito. As diversas faianças,

44 A correspondência consular relativa a comércio e indústria era encaminhada ao Ministère du commerce et industrie pelo Ministère des affaires étrangères.

45 Archives Nationales de France, Série F12/7419, Dossier des porcelaines et liqueurs conduzida pelo Ministère des affaires étrangères junto a consulados da França em várias cidades do mundo, 1883. Na América do Sul, Buenos Aires, Montevidéu, Rio de Janeiro, Valparaíso.

46 "A porcelana de Limoges é geralmente considerada, nos Estados Unidos, como mercadoria de primeira ordem; os números da exportação apresentados pelas estatísticas estabelecidas na França, destacam bastante a importância crescente deste tipo de negócio. / As porcelanas francesas que são enviadas a Nova York, seja a partir do Havre, seja de Bordeaux, encontram escoamento fácil nos Estados Unidos e geralmente não são importadas em quantidades suficientes para responder a todas as demandas". Archives Nationales de France, Série F12/7419, Dossier des porcelaines et liqueurs, 1883. 
especialmente as inglesas e alemãs, são geralmente mais usadas por causa de seus preços baixos".

Elementos de caráter cultural, na visão dos cônsules, são também apreensíveis a partir da comparação entre as respostas sobre os tipos de produtos vendidos localmente: enquanto na Pérsia (atual Irã) "os serviços completos de mesa são desconhecidos", "nas casas ricas se encontram vasos desparelhados e de procedências diversas" e as peças "cujo uso é desconhecido são colocadas em estantes, muito numerosas nas casas persas, como decoração", no Rio de Janeiro "toda a fabricação do artigo se aplica aos usos do país. Não se pode falar realmente de alguma especialidade nas vendas". A este propóstio, Lima (2007, p.21) observou que o uso de objetos, no Brasil do século XIX, para finalidades diferentes daquelas para as quais foram originalmente concebidos em razão da inadequação das importações às necessidades locais.

No Rio de Janeiro, o cônsul G. Delongraye assinala, entre outras coisas, que "a porcelana francesa encontra uma concorrência seríssima no artigo inglês conhecido como porcelana opaca, que, para fins tarifários, teve o privilégio de ser considerado como faiança." As respostas de Delongraye ao questionário desta enquete geram, na França, um protesto da Câmara Sindical da Cerâmica e da Vidraria, ao qual o cônsul responde. Tais registros públicos revelam-nos, hoje, ainda outros detalhes sobre a porcelana no Brasil: no Rio de Janeiro era usual chamar "porcelana opaca" ou "porcelana inglesa" peças que tecnicamente não são porcelanas e sim faianças de granito (chamadas pó-de-pedra). Também avaliações sobre aspectos culturais relativos a brasileiros e franceses podem ser vislumbrados (assim como estratégias comerciais inglesas e alemãs), quando o cônsul Delongraye afirma:

Escrevi muitas vezes, em diferentes momentos, que a massa das populações americanas se contenta com produtos de segunda, de aspecto agradável e preço reduzido, e que esse tipo de produção atrapalha imensamente o comércio exterior da França, nossos industriais se obstinando em não fabricar nas condições desejadas, estudadas por nossos concorrentes (que enviam agentes especiais para este fim) para estender 
seu comércio na América. Assim é que os números de nossa exportação no Rio de Janeiro mantêm-se estacionários há 30 anos, enquanto os números da Inglaterra e da Alemanha cresceram em proporções alarmantes para nós. / E uma vez que há muito tempo a França produz louça de granito, de quem será a culpa se este artigo é absolutamente desconhecido no Rio pelos comerciantes do ramo?

Georges Ritt, primeiro cônsul da França em São Paulo, entre 1895 et $1898,{ }^{47}$ registra que a porcelana de Limoges representava $4 / 5$ de todas as entradas de porcelana no Brasil e que somente o Porto de Santos, no Estado de São Paulo, representava cerca de um terço do total de francos do comércio de porcelanas e faianças no Brasil. Ao mesmo tempo, que rapidamente a porcelana perdia terreno para as faianças finas inglesas e para as faianças comuns da Bélgica, Inglaterra e Alemanha. ${ }^{48}$

O problema da concorrência estabelecida por produtos mais baratos que entravam em grande quantidade no Brasil, tornava-se ainda mais sério para os fabricantes franceses em razão das pesadas taxas que o governo brasileiro impunha aos produtos de luxo:

A Porcelana (...) perdeu muito de sua importância; os negócios que enseja tendem a se restringir cada vez mais por causa da dificuldade em competir, pelos preços de custo, com as faianças similares meio-finas, que causam o mesmo efeito sem custar tão caro. Acrescente-se que

47 No que diz respeito à representação diplomática francesa, anteriormente a 1895, em São Paulo, só havia agentes consulares. O desenvolvimento da cidade e respectiva região geraram a criação de um consulado francês em São Paulo, do qual passaram a depender também os estados de Paraná, Santa Catarina e Rio Grande do Sul. Uma sensível diminuição das exportações francesas para o Brasil, nos anos 1890, foi razão para outro reforço diplomático, o envio, ao Brasil, pelo governo da França, de um ministro plenipotenciário encarregado de estudos e ações diplomáticas mais efetivas (Archives de la Chambre de Commerce et d'industrie Marseille-Provence, 1899, Série MQ53/07). Tratava-se do Sr. Wiener, que chefiou uma Legação em Petrópolis.

48 Archives Nationales de France, Série F12/7052, "Annexe à Dépêche commerciale du 20 décembre [1896] sur le commerce des porcelaines et faïences, de la verrerie et cristallerie à São Paulo". 
as taxas aduaneiras são particularmente rigorosas sobre a porcelana propriamente dita, ultrapassando em 60 a $80 \%$ o valor do artigo (...). ${ }^{49}$

O problema das taxas era em grande medida político. Em várias ocasiões e em diferentes momentos ao longo do século XIX, os cônsules franceses se queixam das facilidades oferecidas aos produtos ingleses, pelo governo brasileiro, por meio de uma legislação que lhes é francamente favorável, em detrimento dos produtos franceses. Os acordos e conflitos políticos se fazem sentir na "guerra das tarifas" e é neste sentido que em 1899 o governo brasileiro apresenta um projeto de lei destinado a sobretaxar as mercadorias francesas em sua entrada no país, em resposta às enormes taxas impostas pela França à entrada do café do Brasil. Em reação ao anúncio desta medida, a manufatura de porcelanas de Barny \& Rigoni solicitou à Câmara de Comércio de Limoges uma ação junto ao governo francês a fim de reduzir as taxas cobradas pela duana francesa sobre o café brasileiro, consideradas, efetivamente, exorbitantes. Para bem fundamentar esta solicitação, a ela juntou-se um Rapport de la Commission de l'Union des fabricants de porcelaine du Limousin sur le conflit douanier imminent entre la France et le Brésil, ${ }^{50}$ no qual, além dos raciocínios econômicos, evocou-se a simpatia dos brasileiros pela França e toda uma história de amizade entre os dois países. O documento é assinado por cinco representantes de manufaturas e casas de exportação/importação: W. Guérin, H. Boudet, Baron de la Bastide, J. Rouchon (no Rio de Janeiro), J. Rigoni. ${ }^{51}$ Uma cópia da carta escrita ao Ministro do Comércio e Indústria pela Câmara de Comércio de Limoges foi enviada a outras câmaras de comércio por toda a França

49 Archives Nationales de France, Série F12/7052, "Annexe à Dépêche commerciale du 20 déc. [1896] sur le commerce des porcelaines et faïences, de la verrerie et cristallerie à São Paulo".

50 Archives de la Chambre de Commerce et d'industrie Marseille-Provence, 1899, Série MQ53/07.

51 O documento menciona que dois de seus cinco signatários tinham vivido no Brasil, onde mantinham negócios há muito tempo Um deles podemos supor que seja Jules Rouchon; o outro não pudemos identificar. 
com o objetivo de obter-se o seu apoio. Daí resultou que várias delas, assim como outras organizações, se manifestaram ao Ministro. ${ }^{52}$

Apesar, porém, de todas essas dificuldades, as exportações de porcelanas da França para o Brasil continuavam a ter importância econômica suficiente para figurar como ramo de comércio específico (ou associado à vidraria, senão às louças em geral) na maior parte dos muitos balanços estatísticos que se encontram na correspondência consular em questão.

Uma tabela elaborada pelo cônsul da França em São Paulo, a partir de dados fornecidos pela duana brasileira, permite que se tenha uma idéia da quantidade de louça em geral que entrou pelo Porto de Santos no trimestre de agosto a outubro de 1897: "louçaria em geral, sem designação, na maior parte faiança - 758 volumes — peso de 179.644 kilos" ${ }^{53}$ Em 1899, um relatório referente à estatística aduaneira sobre o Porto do Rio de Janeiro indicava:

\section{Classe XXI (Porcelana e Vidraria)}

As importações relativas a esta classe atingiram 207.989 milréis de valor oficial e 105.720 milréis de percepções aduaneiras.

Nesta classe convém distinguir:

$1^{\circ}$ As FAIANÇAS comuns, pó-de-pedra, etc, de todas as qualidades e usos (65.400 kilos e 34.600 milréis provenientes principalmente da Inglaterra (37.600 kilos e 20.200 milréis); da Bélgica (20.600 kilos e 100.000 milréis); da Alemanha (5.200 kilos e 3.200 milréis) e muito pouco da França (600 kilos e 1.400 milréis).

52 Archives Nationales de France, Série F12/6490, cartas dirigidas ao Ministre du Commerce et d'Industrie por diversas câmaras de comércio; câmaras sindicais; Câmara de Comércio de Exportação, Câmara de Negociantes Comissários e do Comércio Exterior e Companhia de Navegação Chergeurs Réunis.

53 Archives Nationales de France, Série F12/7052, 18 jan. 1898. 
$2^{\circ}$ A PORCELANA fina, de proveniência principalmente francesa $(10.742$ kilos e 15.247 milréis sobre um total de 12.702 kilos e 20.041 milréis). No que se refere a este artigo, os envios da Alemanha não passaram de 1.917 kilos e 4.657 milréis e os envios da Inglaterra foram irrisórios (43 kilos e 136 milréis)! ${ }^{54}$

\section{OS COMERCIANTES}

A compreensão do sistema de comércio de porcelanas francesas no Brasil passa, evidentemente, pelo levantamento dos comerciantes que se dedicavam a esta atividade no país. Para constituirmos o elenco dos principais importadores desse tipo de artigo e suas casas comerciais no Rio de Janeiro, então capital do Brasil, partimos de algumas fontes documentais escritas - principalmente a correspondência do consulado francês, o Jornal do Commercio (RJ) e o Almanaque Laemmert $-{ }^{55}$ mas também das marcas presentes em peças do acervo do Museu Paulista. Falaremos aqui de apenas uma casa comercial, associada a um serviço de mesa de que foi a importadora: Rouchon Irmãos.

No que diz respeito à segunda metade do século XIX no Rio de Janeiro, retomemos as respostas do cônsul da França à enquete de 1883, acima citada, na qual são indicadas, pelo Côsul G. Delongraye, casas comerciais do Rio de Janeiro para o comércio de porcelanas: "Há no mercado várias casas de importação que mantêm relações diretas com os fabricantes. Estas casas são as dos srs. Rouchon frères, que contam com um agente em Limoges; Sr. Milliet fils; e dos srs. Thiesen \& $C^{\text {ie }}$, com casa em Paris". ${ }^{66}$

54 Archives Nationales de France, Série F12/7052, Estatística aduaneira de importação no Rio de Janeiro, em janeiro de 1899. Grifos nossos.

55 ALMANAK administrativo, mercantil, e industrial do Rio de Janeiro ("Almanaque Laemmert”). Rio de Janeiro: irmãos Eduardo e Henrique Laemmert, 1844 a 1889.

56 Archives Nationales de France, Série F12/7419, Dossier des porcelaines et liqueurs. 
No Almanaque Laemmert para o mesmo ano, na rubrica "Louça, Porcellana, Electroplate, Negociantes, Lojas e Armazéns de)”, havia 97 casas comerciais elencadas. Aí estavam incluídos, porém, negócios variados, como indicava o próprio subtítulo desta rubrica, "Christofle, Crystaes, Casquinhas, Bandejas, Lampeões”. Podia tratar-se de lojas finas da rua do Ouvidor, que entre outros artigos vendiam também louças e porcelanas, ou lojas de artigos comuns e diversos, que não fizessem suas próprias importações. Entre aquela centena de nomes, constavam dois dos importadores citados pelo relatório do Cônsul Delagraye: M. Milliet Fils e Thiesen \& C ${ }^{\text {ie }}$ mas não Rouchon Frères, que constavam, porém, na rubrica "Importação/Exportação".

Rouchon frères ou Rouchon Irmãos - o nome desta firma, utilizado tanto em francês como em português, pertencente aos irmãos Camille e Jules Rouchon, ${ }^{57}$ aparece pela primeira vez no Jornal do Commercio em $1867 .{ }^{58}$ No Almanaque Laemmert, depois de constar de 1868 a 1876 na rubrica referente aos comerciantes de louças e porcelanas ("Armazéns e Lojas de Louça, porcelanas, vidros, cristais, bandejas e bronzes”), como "Rouchon Irmãos, r. do Sabão [não mais existente hoje], 70 (Deposito por atacado e comissão)" 59 —, só voltaria a constar em 1882 mas agora na rubrica "Importação, Exportação" ${ }^{60}$

Percorrendo os manifestos de importação regularmente publicados no Jornal do Commercio, constatamos que Rouchon Irmãos era uma das firmas que mais importações de louça e porcelanas fazia naqueles anos. Embora também importassem constantemente artigos como vidros, ferragens, utensílios domésticos e vinhos, era nas louças e porcelanas que se concentravam suas encomendas. Por isso, já no Almanaque de 1885, mesmo na rubrica referente às importações e não às louças e porcelanas,

57 NÉCROLOGIE. - M. Camille Rouchon... L’Etoile du Sud, ed. 00015, 12 abr. 1908, p.4-5.

58 RELAÇÃO dos despachos de importação pagos no dia 29 de Setembro de 1867. Jornal do Commércio (RJ), ed. 000274, 2 out. 1867, p.3.

59 Almanaque Laemmert para 1868, p.584-585.

60 Almanaque Laemmert para 1882, p.339. A própria rubrica "Importação, Exportação" havia sido introduzida no anuário daquele ano e congregava grande número de negociantes. 
passaram a assinalar seu ramo mais circunscrito de especialidade, indicações estas que se mantiveram por anos a fio: ${ }^{61}$ "Rouchon Irmãos, importação, r. do Hospicio [atual rua Buenos Aires], 93, Teleph. 265. Importadores de porcelanas francezas, louça da fábrica de Utzschneider \& C., de Sarreguemines, crystaes de Baccarat, metal Christofle e outros artigos".62

Encontra-se Jules Rouchon, da Maison Rouchon frères, como conselheiro do bureau da Câmara de Comércio Francesa do Rio de Janeiro - CCFRJ - para o exercício de 1890-189163 e como seu membro ativo em 1912. ${ }^{64}$ Em 1899, sob razão social de Rouchon \& C. ${ }^{65}$ J. Rouchon é um dos cinco signatários do documento produzido pela Comissão da União dos Fabricantes de Porcelana citado acima ${ }^{66}$ No Boletim de abril de 1912 da CCFRJ, a casa Rouchon \& C. se apresenta como comércio de "Importação, Comissão, Faianças" ${ }^{67}$ Registros em jornais mostram a casa Rouchon presente, constantemente, entre outras empresas francesas, nas comemorações da festa nacional de 14 de Julho organizadas pela colônia francesa do Rio de Janeiro. ${ }^{68}$

Como se vê pelo elenco de artigos que oferecia, não era um estabelecimento exclusivo de porcelanas ou de artigos de luxo, mas sim de produtos de diferentes tipos e louças de diferentes níveis de qualidade. Incluía, porém, o fornecimento de porcelana de luxo, feita sob encomenda, o que se comprova por alguns documentos comerciais da firma

61 Rouchon \& C. continua presente nos almanaques Laemmert até o final dos anos 1920, mas não examinamos esse período.

62 Almanaque Laemmert, 1885, p.665.

63 A existência de uma Câmara de Comércio Francesa do Rio de Janeiro (CCFRJ) já nos anos 1890 é hoje um fato desconhecido e a data oficial de sua criação é 18 de maio de 1901. Funde-se com a Câmara de Comércio Francesa de São Paulo em 1927, dando origem a um novo órgão denominado Câmara de Comércio Francesa do Brasil (Archives de la Chambre de Commerce de Paris, Réf. I.4.50(1), années 1920-1921).

64 Boletim da CCFRJ, 1890, 1891, 1912.

65 Almanaque Laemmert para 1899, p.1526.

66 Archives de la Chambre de Commerce et d'industrie Marseille-Provence, 1899, Série MQ53/07.

67 Bulletin de la CCFRJ, 1912.

68 Entre outros, jornal O Paiz, 12 jun. 1885; 26 jun. 1886; 17 jun. 1888. 
Rouchon preservados na Casa do Pinhal (Fazenda Pinhal, cidade de São Carlos, Estado de São Paulo), que fazem menção a porcelanas, juntamente com cristais e metais. Fazem parte de uma série de documentos relacionados a compras realizadas em 1888, no Rio de Janeiro, junto a casas importadoras. ${ }^{69}$ Dois deles, datados de 31 de março de $1888,{ }^{70}$ tratam de uma grande encomenda, que inclui um serviço de mesa em porcelana e um serviço em cristal, que se pode depreender concebidos para uso conjunto (já que para os cristais indica-se que deveriam ser feitos no "padrão do serviço para jantar") ${ }^{71}$ A encomenda havia sido feita pelo Conde do Pinhal, Antônio Carlos de Arruda Botelho, à firma Rouchon Irmãos, por intermédio do Comendador José Ribeiro de Freitas. O papel utilizado apresenta algo como uma marca d'água com o monograma "CP" do Conde do Pinhal, o mesmo que foi pintado em cada uma das peças de porcelana e lavrado em cada peça de cristal.

O primeiro documento, ${ }^{72}$ com carimbo de Rouchon Frères, refere-se à remessa da fatura e demais registros relativos à compra de "louças de porcelana fina e cristais". O segundo documento, ${ }^{73}$ em papel timbrado de Rouchon Irmãos, traz, na primeira folha, um resumo dessa encomenda e uma declaração de recibo de $\mathrm{R}$ \$3:521.510 (3 contos e quinhentos e vinte e um mil e quinhentos e dez réis) pelo total da compra, sendo $\mathrm{R}$ 1:969.140 referentes às porcelanas e $\mathrm{R} \$ 1: 190.730$ aos cristais; nas outras 4 folhas, detalha as peças do serviço de porcelana, como veremos a seguir, assim como as de um serviço de cristal e algumas peças Christofle (prata).

69 CASA DO PINHAL, acervo digital, documentos textuais ID 3777 a 3789, disponíveis em http://www.casadopinhal.com.br/ Acesso em 7 ago. 2018. Não trataremos das demais encomendas mas é interessante observar que uma delas, feita ao já citado Luiz de Rezende (ID 3783), refere-se às pratas, que também viriam a compor a mesa do Conde e a Condessa do Pinhal. Luiz de Rezende é também mencionado, associado às "pratas", num documento de Rouchon (ID 3781), o que indica que diferentes fornecedores poderiam atuar em conjunto para atendar a uma encomenda).

70 Casa do Pinhal, ID 3784 e 3785.

71 Casa do Pinhal, ID 3785, fls $2 \mathrm{v}^{\circ}$.

72 Casa do Pinhal, ID 1784.

73 Casa do Pinhal, ID 1785. 
A encomenda havia sido feita em 9 de janeiro de 1888 e expedida no Havre com destino ao Porto de Santos, aonde foi trazida pelo navio Ville de Pernambuco. Pode-se perceber, assim, que menos de três meses foram requeridos para atendê-la. Ao final do documento, Rouchon assinala: "Desejando que sua encomenda chegue em tempo...", frase que nos permite supor que o serviço tivesse sido encomendado para alguma ocasião em especial. Seria talvez tardio se fosse apenas para marcar o recebimento do título de Conde, que havia sido conferido ao titular em 7 de maio do ano anterior ${ }^{74}$ mas dizia respeito, certamente, às bodas de prata do Conde e a Condessa do Pinhal, completadas em 23 de abril de 1888 e festejadas na Fazenda Pinhal, provavelmente nessa data ou em torno dela (Gordinho, 1985, p.74).

Para o transporte transatlântico, tudo havia sido acondicionado em nove barricas, sendo quatro delas para as porcelanas e cinco para os cristais. As porcelanas foram descritas como "aparelho para jantar feitio liso com pé, padrão Medicis, cor rubi e ouro com coroa de Conde e monograma $\mathrm{CP}$, pintados, composição para 120 pessoas como acima mencionado." Nas peças deste serviço existentes no acervo do Museu Paulista (figura 3), vê-se que são predominantemente brancas, com a maior parte das superfícies apenas revestidas por vitrificação (recobertas por esmalte incolor), que faz com que, no processo de fabricação, depois de a peça ser revestida e levada ao forno, o branco ganhe um aspecto mais liso, homogêneo e brilhante, sublinhando as características da porcelana. A cor designada como rubi foi usada para frisos que trazem um delicado motivo decorativo em brancos e dourados, que, segundo Dreyfus, representariam grãos de café. Esses frisos apresentam-se entre filetes dourados e as dourações encontram-se igualmente em detalhes dos pegadores, asas e pés, além de o ouro ter sido utilizado também para o monograma coroado (Dreyfus, 1982, p.307).

74 VASCONCELLOS, Barão de; VASCONCELLOS, Barão Smith de. Archivo nobiliarchico brasileiro. Lausanne (Suisse): La Concorde, 1918, p.355-356. 
Figura 3: Terrina para sopa (ou sopeira) do Serviço do Conde do Pinhal, 1888. Traz a marca da manufatura Jean Pouyat, Limoges.

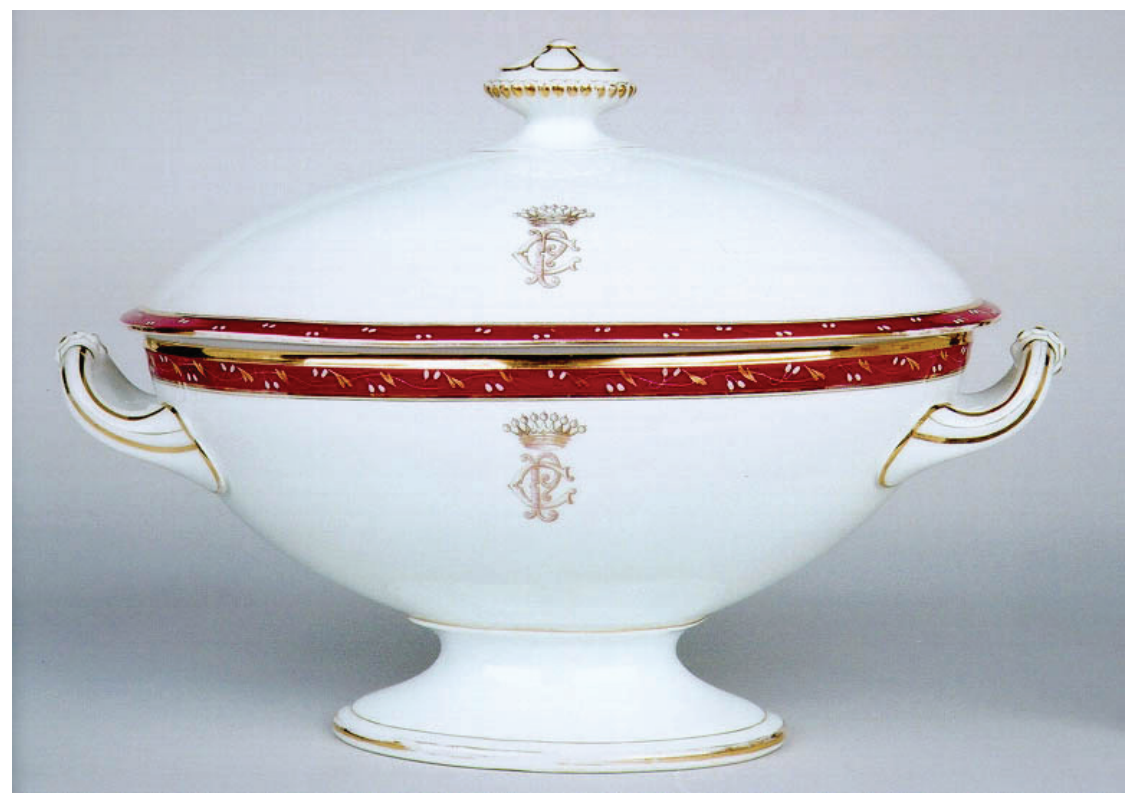

Fonte: Acervo do Museu Paulista da Universidade de São Paulo Créditos fotográficos: Hélio Nobre e José Rosael

O detalhamento de todos os tipos de peças que compunham esse aparelho (ou serviço) revela o requinte das artes da mesa, tal como eram praticadas pelas elites européias, assim como de diversos países mundo afora, como as norte-americanas e as brasileiras. Isto porque além da exuberância das quantidades; do reluzir das vitrificações em branco, contracenando com as dourações e as colorações decorativas; do tilintar com a sonoridade típica da porcelana fina, que se faria ouvir nos momentos de movimentação das peças, para pôr a mesa, por exemplo; o requinte residia também na utilização de peças com diferentes formas, destinadas a funções específicas ao longo das refeições. Assim, além das 30 dúzias de pratos rasos, 12 dúzias de pratos fundos e 20 dúzias de pratos de sobremesa, havia 12 molheiras, 36 conchas para conservas, 50 travessas em 5 tamanhos diferentes, além de outras 4 específicas para peixe e mais 12 pratos para forno, 8 terrinas ovais para sopa [sopeiras], 
8 saladeiras, 6 terrinas para molho, 18 fruteiras com pé, recortados (sic), 12 pratos com pé alto, 6 cremeiras ovais [espécies de bandejas] com lugar para 12 potes cada uma e os 72 potes correspondentes para creme, 6 pratos de três andares para doces secos e 24 "cobertos ovais" [couverts?]. Assim, em termos unitários, tratava-se de um serviço com 1018 peças de porcelana, distribuídas por 21 tipos.

Este serviço de mesa, assim como um outro, também comprado em 1888 e descrito como "um aparelho para jantar Padrão [Cór?] e Ouro, com monograma C.P. (Letra principal P), Coroa de Conde acima do monograma", ${ }^{75}$ existe ainda hoje na Fazenda Pinhal. Daquele primeiro, que podemos chamar de "serviço rubi", 6 peças, integram o acervo do Museu Paulista.

A importação desses serviços personalizados para o Conde do Pinhal pela casa Rouchon pode ter sido algo de envergadura excepcional mas não um caso isolado, já que era constante, nos manifestos de importação publicados em jornal, o registro de barricas de porcelanas ou louças, procedentes de Bordeaux ou Marselha, recebidas por Rouchon Irmãos. ${ }^{76}$ Por exemplo: Barca francesa Rose C., de Marselha: Louça: 212 barricas a Rouchon Frères. ${ }^{77}$ Uma vez que se tratava de um depósito (e não de comércio de varejo, ao que tudo indica), é possível que Rouchon Frères, além de praticar vendas diretamente aos seus clientes, como no caso acima, fornecesse porcelanas também a outros comerciantes do ramo.

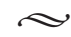

A partir de tudo o que acabamos de examinar, percebe-se, na segunda metade do século XIX, um quadro geral, formado nas décadas precedentes, marcado por uma forte concorrência comercial em que os franceses se viam gradativamente ultrapassados em volume de vendas por ingleses e alemães. O governo francês tentava intervir no comércio

75 Casa do Pinhal, Arquivo, ID 3782.

76 Jornal do Commercio (RJ), anos 1880.

77 Jornal do Commercio (RJ), ed. 119, 29 abr. 1884, p.4. 
para organizá-lo e desenvolvê-lo, mas os fabricantes e comerciantes franceses preferiam se manter em seu sistema de relações diretas com comerciantes brasileiros ou instalados no Brasil.

Em vista da diminuição progressiva das exportações francesas para o Brasil, os cônsules da França criticam os fabricantes de seu país por não utilizarem as mesmas estratégias de seus concorrentes estrangeiros: "É absolutamente necessário que os fabricantes e negociantes se apressem em estudar cuidadosamente os produtos similares dos estrangeiros, nossos concorrentes, que expedem para o Brasil artigos mais apropriados às necessidades e ao gosto da população, certamente de qualidade inferior, mas de venda muito mais fácil em razão de seu baixo preço".78

Parece-nos, no entanto, que havia razões fortes para que os fabricantes não quisessem mudar seu método de trabalho. Antes de tudo, uma tradição de excelência, de refinamento no campo das artes decorativas, que fazia a diferença qualitativa e estética do produto francês. Associada a esta tradição, a imagem deste produto, o sentido que ele adquire para os que o compram: a porcelana francesa jamais viria a ser realmente destinada a um consumo popular ou burguês; manter-se-ia sempre voltada ao consumo de uma elite que pagava caro por ela, justamente por suas características técnicas e estéticas e para tê-la com exclusividade. Além do mais, também não conviria produzir objetos ao gosto local; o próprio gosto francês era o gosto cultivado pela elite nacional no processo de desenvolvimento de seus hábitos e de sua imagem de classe.

Deste modo, se para a economia nacional francesa seria desejável que os fabricantes franceses se lançassem no mercado brasileiro para vender faiança e louça comum em grandes quantidades, para os fabricantes e comerciantes de porcelanas daquele país era preferível reservar o produto francês a um consumo de elite. Assim, é provável que apesar da diminuição geral nas vendas de porcelanas, alguns fabricantes tenham feito bons negócios a preços muito altos e que certos comerciantes tenham enriquecido ao fazer da porcelana fina francesa uma espécie de

78 Archives Nationales de France, Série F12/7052, documento de 17 dez. 1884. 
ponta-de-lança para todos os outros artigos relativos às artes da mesa, em diferentes níveis de qualidade.

De fato, para a elite brasileira, os serviços de mesa em porcelana francesa eram bens especiais, exibidos nas residências urbanas ou das fazendas, em cristaleiras, ou em uso, por ocasião de festas e banquetes. No dia a dia, esta mesma elite usava faianças finas inglesas (Lima, 1995).

Pode-se dizer, então, que se a porcelana francesa tinha, apesar de todas as dificuldades comerciais, uma importância econômica, seu valor realmente mais forte era simbólico. Sua estética, qualidade e origem desempenhavam um papel de destaque no aparato das elites brasileiras no século XIX.

\section{Agradecimentos}

Este artigo resulta parcialmente de pesquisa realizada como pesquisadora convidada do Centre André Chastel - Université de Paris IVSorbonne, acolhida pela Equipe André Félibien e Professor Bathélemy Jobert, a quem agradecemos, assim como a Antoinette Fay-Hallée, diretora do Musée national de la céramique, em Sévres, e a Chantal Meslin-Perrier, diretora do Musée national de la porcelaine Adrien Dubouché, em Limoges, entre vários outros especialistas franceses que muito nos ensinaram mas cujo elenco ficaria longo demais para os contornos deste artigo. A pesquisa contou com apoio da FAPESP. Por razões diversas, permaneceu inédita desde seu desenvolvimento inicial, em 2005, e agora foi retrabalhada e ampliada para apresentação deste artigo.

\section{REFERÊNCIAS BIBLIOGRÁFICAS}

ALBIS, Laurens d. Haviland et la révolution du décor, 1873-1885. Dossier de l'art, n. 12, p.56-62, Mai-Juin, 1993.

ALBIS, Laurens d'. Le début du japonisme céramique en France de Bracquemond à Chaplet. Sèvres: Revue de la Société des Amis du Musée National de la Céramique, n. 7, p.13-15, 1998. 
ALBIS, Jean d'; HORTS, Noëlle des. La porcelaine des Pouyats. Paris: Varia, 1992.

ALGRANTI, Leila Mezan. Alimentação e cultura material no Rio de Janeiro dos vice-reis: diversidade de fontes e possibilidades de abordagens. Varia Historia, Belo Horizonte, vol. 32, n. 58, p.21-51, jan./abr. 2016.

ARAÚJO, Emanoel. O Café. São Paulo: Banco Real, 2000. (Catálogo da exposição).

BON, Philippe. Les Chemins de la porcelaine en Berry. S.l.: Na Nouvelle République du Centre-Ouest, 1998.

BORREGO, Maria Aparecida de Menezes. Artefatos e práticas sociais em torno das refeições (São Paulo, séculos XVIII e XIX). Varia Historia, Belo Horizonte, vol. 32, n. 58, p.101-137, jan./abr. 2016.

BOUILLON, Jean-Paul; MESLIN-PERRIER, Chantal. Félix Bracquemond et les arts décoratifs. Du japonisme à l'Art nouveau. Paris: Réunion des Musées Nationaux, 2005. (Catálogo de exposição).

BRUNET, Marcelle; PREAUD, Tamara. Sèvres, des origines à nos jours. Fribourg (Suisse): Office du Livre, 1978.

DREYFUS, Jenny. A Louça da aristocracia no Brasil. Rio de Janeiro: Monteiro Soares Editores, 1982.

ENNÈS, Pierre. Four plates from the Sèvres Service des arts industriels (1820-1835). Journal of the Museum of Fine Arts Boston, vol. 2, p. 89-108, 1990.

FAVIER, Jean (org.) Guide des sources de l'histoire de l'Amérique Latine et des Antilles dans les archives françaises. Paris: Archives Nationales de France, 1984.

FAY-HALLÉ, Antoinette; MUNDT, Barbara. La Porcelaine européenne au XIXe siècle. Friboug (Suisse): Office du Livre, 1983.

GORDINHO, Margarida Cintra. A Casa do Pinhal. São Paulo: Knapp. 1985.

GUILLEBON, Régine de Plinval de. Fä̈ence et porcelaine de Paris, XVIIIe-XIXe siècles. Paris: Faton, 1995.

KNAUSS, Paulo. O cavalete e a paleta: arte e prática de colecionar no Brasil. Anais do Museu Histórico Nacional, vol. 33, p.23-44, 2001.

L'ECOLE DE NANCY: fleurs et ornements; ma racine est au fond des bois. Paris: Réunion des musées nationaux, 1999. (Catálogo de exposição). 
LIMA, Tânia Andrade. Pratos e mais pratos: louças domésticas, divisões culturais e limites sociais no Rio de Janeiro, século XIX. Anais do Museu Paulista: história e cultura material. São Paulo, N. Sér., vol. 3, p.129-191, jan./dez. 1995.

LIMA, Tânia Andrade. "Cultura material, hibridação e dominação planetária: a globalização nos museus históricos". In: ASSOCIAÇÃO INTERNACIONAL DE MUSEUS DE HISTÓRIA. Como organizar um mundo multipolarizado? Paris: Association Internationale des Musés d'Histoire; São Paulo: Museu Paulista da USP, 2007. p.18-26. (Anais do $7^{\circ}$ Colóquio da AIMH).

LONG, Derek A. Sèvres Service des Arts Industriels. Tools and Trades, vol. 9, p.28-52, 1996.

MARTINS, Mariana Esteves. A formação do Museu Republicano "Convenção de Itu”, 1921-1946. Dissertação (Mestrado em História) - Universidade de São Paulo. São Paulo, 2012.

MESLIN-PERRIER, Chantal. Pouyat, 1835-1912. Limoges: Centre Impression, 1994.

MESLIN-PERRIER, Chantal; SEGONDS-PERRIER, Marie. Limoges, deux siècles de porcelaine. Paris: L’Amateur; Réunions des Musées Nationaux, 2005.

MOURA, Carlos Eugênio Marcondes de. "Os titulares do Império no Vale do Paraíba paulista”. In: MOURA, Carlos Eugênio Marcondes de. $O$ Visconde de Guaratinguetá: um fazendeiro de café no Vale do Paraíba. São Paulo: Studio Nobel, 2002. p.103-106.

MOURA, Carlos Eugênio Marcondes de (org.) Fazendas de café do Vale do Paraíba: o que os inventários revelam (1817-1915). São Paulo: Condephaat, 2014.

SANTOS, José de Almeida. Mobiliário artístico brasileiro. São Paulo: Museu Paulista, 1963. 3v. (Col. Museu Paulista).

VALIÈRE, Nathalie. Un Américain à Limoges: Charles-Edward Haviland, 1839-1921, porcelainier. Tulle: Lemouzi, 1992. 